\title{
THE ENDOTHELIN ANTAGONIST BOSENTAN: HEMODYNAMIC EFFECTS DURING NORMOXIA AND HYPOXIC PULMONARY HYPERTENSION IN PIGS
}

Peter Holm, MD

Jan Liska, MD, $\mathrm{PhD}^{\mathrm{a}}$

Martine Clozel, $\mathrm{PhD}^{\mathrm{b}}$

Anders Franco-Cereceda, MD, $\mathrm{PhD}^{\mathrm{a}}$
In this study, we investigated the hemodynamic effects and receptorblocking properties of the nonselective endothelin antagonist bosentan in pigs during normoxia and acute hypoxia. Hypoxic pulmonary hypertension was induced by decreasing the fraction of inhaled oxygen to 0.1 . In a control group of pigs, hemodynamic parameters proved to be stable through 2 hours of hypoxia. Infusions of endothelin-1, endothelin-3, and sarafotoxin $6 \mathrm{c}$ into the pulmonary artery resulted in pulmonary and systemic vasoconstriction during normoxia, whereas endothelin administration during hypoxic pulmonary hypertension resulted in pulmonary vasodilation. After administration of bosentan, the vasopressor effect of endothelin-1 during normoxia was significantly attenuated and the pulmonary vasodilatory effect of endothelin-1 during hypoxia was reduced. Furthermore, the development of hypoxic pulmonary hypertension was significantly reduced by bosentan. In contrast, bosentan did not influence the pulmonary vasopressor response to the thromboxane mimic U-46619. We therefore conclude that vasopressor endothelin receptors seem to be activated by endogenous endothelin released during hypoxia, leading to an increase in the pulmonary vascular tone. (J Thorac Cardiovasc Surg 1996;112:890-7)
$E_{\mathrm{p}}^{\mathrm{n}}$ dothelins (ETs) are a group of isopeptides with potent vasoactive properties. ${ }^{1}$ Three isopeptides, ET-1, ET-2, and ET-3, have been documented; ET-1 is the main ET produced by the vascular endothelium. $^{2}$ The vascular effects of ETs are mediated by at least two endothelin receptors, $\mathrm{ET}_{\mathrm{A}}$ and $E T_{B}$. The $E T_{A}$ receptor is selective for ET-1 and causes vasoconstriction, whereas the $E T_{B}$ receptor is nonselective and is considered to mediate endothelium-dependent vasodilation. ${ }^{3}$

ET-1 elicits variable effects in different vascular tissues. Studies on the pulmonary circulation have

From the Department of Thoracic Surgery Karolinska Hospital, Stockholm, Sweden, ${ }^{a}$ and F. Hoffmann-La Roche, Basel, Switzerland. ${ }^{\mathrm{b}}$

Supported by grants from the Heart-Lung Foundation, the Swedish Medical Research Council, the Wallenberg foundation, the Thuring foundation, the Swedish Society of Medicine, the Salus Foundation, the Bergman Foundation, the Wiberg Foundation and funds from the Karolinska Institute.

Received for publication Dec. 11, 1995; revisions requested Jan. 29, 1996; revisions received Feb. 26, 1996; accepted for publication March 4, 1996.

Address for reprints: Peter Holm, MD, Department of Thoracic Surgery, Karolinska Hospital, 17176 Stockholm, Sweden.

Copyright (C) 1996 by Mosby-Year Book, Inc.

$0022-5223 / 96 \$ 5.00+0 \quad \mathbf{1 2 / 1 / 7 3 2 4 1}$ shown ET-1 to produce isolated vasoconstriction or transient vasodilation followed by vasoconstriction., 5 The effects of ET-1 on the pulmonary circulation vary depending on a number of factors, including species studied, age of studied animals, and vasomotor tonus of the pulmonary vascular bed; effects are also, at least in part, dependent on mode of administration. ${ }^{3}$ Several studies showed that low doses of ET-1 may produce vasodilation when the pulmonary vascular tone is increased by hypoxia or vasoconstrictive agents. ${ }^{6,7}$ Various pathologic conditions with pulmonary hypertension have been found to be associated with elevated levels of ET$1^{8,9}$ In patients with congenital heart defects and pulmonary hypertension, elevated plasma ET-1 levels have been reported to correlate with both increased pulmonary blood flow and pulmonary vasoreactivity during hypoxia. ${ }^{10,11}$ In addition, these patients have been noted to have relatively greater increase in plasma levels of ET-1 during and after cardiopulmonary bypass, correlating with pulmonary pressure and suggesting that high endothelin levels may predispose patients toward pulmonary hypertensive crisis during the postoperative period. $^{12}$

We recently reported that $\mathrm{ET}$ infusion reduces pulmonary hypertension during acute hypoxia in 
pigs. ${ }^{13}$ To further investigate the role of ET-receptor activity in pulmonary hypoxic hypertension, in this study we evaluated the effects of combined

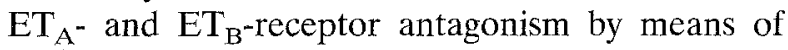
bosentan in pigs subjected to acute hypoxia. Bosentan, an orally active, nonselective ET antagonist, was developed for ${ }^{14}$ and used in evaluation of the role of ETs in pathologic conditions in experimental animals and human beings. ${ }^{15}$ First, the stability of the model was characterized by long-term hypoxia ( 2 hours). Hemodynamic parameters during long-term infusion of ETs were evaluated during normoxia and hypoxia, because ET infusion has been reported to induce tachyphylaxis. ${ }^{16}$ The effects of bosentan administration were then evaluated during normoxia and hypoxia. The ET-blocking properties were further studied by infusion of ET-1, ET-3, and sarafotoxin $6 \mathrm{c}(\mathrm{S} 6 \mathrm{c})$. S6c, a selective $\mathrm{ET}_{\mathrm{B}}$-receptor agonist, ${ }^{17}$ was used to evaluate the ET-receptor subgroups responsible for ET vasoactivity. To investigate the selectivity of the effects observed after bosentan administration during hypoxia, the thromboxane mimetic U-46619 was used as an alternative means of inducing pulmonary hypertension.

\section{Methods}

The ethics committee of the Karolinska Institute approved the experiments in this study. The investigation conforms with the "Guide for the Care and Use of Laboratory Animals" prepared by the Institute of Laboratory Animal Resources and published by the National Institutes of Health (NIH publication No. 86-23, revised 1985).

Experimental setup. Swedish farm pigs $(32 \pm 1 \mathrm{~kg}$, approximately 4 months old) were premedicated intramuscularly with $20 \mathrm{mg} / \mathrm{kg}$ ketamine. After intravenous anesthesia with $15 \mathrm{mg} / \mathrm{kg}$ sodium pentobarbital, the pigs were intubated and mechanically ventilated (Engström respirator system 3000, Dater-Engström, Bromma, Sweden). A continuous infusion of fentanyl $(10$ $\mu \mathrm{g} \cdot \mathrm{kg}^{-1} \cdot$ hour $\left.{ }^{-1}\right)$, midazolam $\left(100 \mu \mathrm{g} \cdot \mathrm{kg}^{-1} \cdot\right.$ hour $\left.^{-1}\right)$, and pancuronium bromide $\left(150 \mu \mathrm{g} \cdot \mathrm{kg}^{-1} \cdot\right.$ hour $\left.^{-1}\right)$ maintained anesthesia and provided skeletal muscle relaxation. Inspired ventilatory volumes were adjusted to maintain a carbon dioxide tension of 4.0 to $5.0 \mathrm{kPa}$. During normoxia, the pigs were ventilated with room air; hypoxia was created by switching to a gas mixture of $10 \%$ oxygen in $90 \%$ nitrogen to increase pulmonary vascular tone. The fraction of inhaled oxygen was monitored (Serve gas monitor; Siemens AG-Bereiche Medizinische Technik, Erlangen, Germany) throughout the experiments. Acetated Ringer's solution (100 to $150 \mathrm{ml} / \mathrm{hour}$ ) was administered intravenously, and body temperature was kept at $37^{\circ} \mathrm{C}$ with a heating pad. Mean systemic artery pressure (MAP) was measured through a catheter in the left femoral artery. A Swan-Ganz catheter (Baxter Healthcare Corp., Edwards Div., Irvine, Calif.) was introduced through the right jugular vein for measurement of mean pulmonary artery pressure (MPAP), pulmonary capillary wedge pressure (PCWP), and central venous pressure (CVP). Hemodynamic measurements were monitored and recorded continuously (pressure transducer, Peter von Berg Medizintechnik, GmbH, Eglharting, Germany; pressure monitor, Hewlett-Packard 78342 A; HewlettPackard GmbH (Peter von Berg Medizintechnik GmbH); pressure recorder, Gould ES 1000, Gould Electronique, Longjuneau, France). Cardiac output (CO) was measured in duplicate by thermodilution by means of a cardiac output computer (COM-2; Baxter). Pulmonary vascular resistance (PVR) was calculated as (MPAP - PCWP)/ $\mathrm{CO}$; systemic vascular resistance ( $\mathrm{SVR}$ ) was calculated as (MAP - CVP)/CO. Arterial and mixed venous blood samples were obtained simultaneously for measurements of blood gas tension and pH. ET-1, ET-3, S6c (Peninsula Laboratories, Inc, Belmont, Calif.), dissolved in sterile water, and the thromboxane mimic U-46619 (Sigma Chemical Company, St. Louis, Mo.) were infused through the Swan-Ganz catheter into the right ventricle. Bosentan (Hoffmann-La Roche \& Co. AG, Basel, Switzerland) dissolved in $2 \mathrm{ml}$ dimethylsulfoxide and diluted with $48 \mathrm{ml}$ sterile water was infused through the left femoral vein. Blood samples for measurement of circulating ET were obtained simultaneously from the pulmonary artery and descending aorta for determination of plasma concentration of ET-1 by radioimmunoassay; details and characterization of this assay are published elsewhere. ${ }^{18}$

\section{Study protocol}

Hemodynamic effects of 2 hours of hypoxia. A control group of six pigs was subjected to hypoxia only for 2 hours.

Effects of 2-hour infusion of ET-1 and ET-3 during normoxia and hypoxia. The effects of 2-hour infusion of ET-1 and ET-3 $\left(25 \mathrm{ng} \cdot \mathrm{kg}^{-1} \cdot \mathrm{min}^{-1}\right)$ were studied in two separate groups of pigs ( $n=4$ in each group) during normoxia. After cessation of the infusion, the pigs were left to rest for 2 hours and thereafter subjected to hypoxia, during which ET-1 or ET-3 was again infused for 2 hours at $25 \mathrm{ng} \cdot \mathrm{kg}^{-1} \cdot \min ^{-1}$. The dose of ET-1 was chosen on the basis of our previous study, in which low-dose infusion was found to decrease MPAP and PVR. ${ }^{13}$

Effects of S6c infusion during normoxia and hypoxia. To further evaluate the involvement of the $\mathrm{ET}_{\mathbf{B}}$ receptor in the vasodilator response to ET-1 infusion during hypoxia, S6c was infused at increasing doses $(10,25,50$, and 100 $\mathrm{ng} \cdot \mathrm{kg}^{-1} \cdot \min ^{-1}$, 10 minutes each dose, $n=6$ ) during normoxia and (after a resting period of 2 hours) during hypoxia.

Effects of ET infusion after bosentan administration during normoxia. The dose-response relationship of infused ET-1 $\left(10,25,50\right.$, and $100 \mathrm{ng} \cdot \mathrm{kg}^{-1} \cdot \mathrm{min}^{-1}, 10$ minutes each dose) was established, during normoxia in control animals $(n=8)$ and after intravenous bolus injection of bosentan at $3 \mathrm{mg} / \mathrm{kg}(n=4)$ or $10(n=4)$ $\mathrm{mg} / \mathrm{kg}$, administered 30 minutes before ET infusion.

Effects of bosentan on pulmonary hypertension induced by hypoxia or $U-46619$. In addition, the response to 15 minutes of hypoxia was evaluated before and 30 minutes after bosentan administration in separate groups of experiments ( $n=4$ for $3 \mathrm{mg} / \mathrm{kg}$ intravenous bosentan and $n=8$ for $10 \mathrm{mg} / \mathrm{kg}$ intravenous bosentan). The effects of 
Table I. Effects of continuous infusions of ET-1 $\left(25 \mathrm{ng} \cdot \mathrm{kg}^{-1} \cdot \mathrm{min}^{-1}\right)$ or ET-3 $\left(25 \mathrm{ng} \cdot \mathrm{kg}^{-1} \cdot \mathrm{min}^{-1}\right)$ in the pulmonary artery on hemodynamic parameters during hypoxia

\begin{tabular}{|c|c|c|c|c|c|c|c|c|c|c|}
\hline & \multicolumn{5}{|c|}{$E T-1$} & \multicolumn{5}{|c|}{$E T-3$} \\
\hline & Hypoxia & $30 \mathrm{~min}$ & $60 \mathrm{~min}$ & $90 \mathrm{~min}$ & $120 \mathrm{~min}$ & Hypoxia & $30 \mathrm{~min}$ & $60 \mathrm{~min}$ & $90 \min$ & $120 \mathrm{~min}$ \\
\hline $\mathrm{MAP}(\mathrm{mm} \mathrm{Hg})$ & $129 \pm 8$ & $141 \pm 6$ & $148 \pm 4$ & $146 \pm 8$ & $137 \pm 15$ & $115 \pm 10$ & $128 \pm 3$ & $121 \pm 13$ & $124 \pm 15$ & $114 \pm 1$ \\
\hline MPAP $(\mathrm{mm} \mathrm{Hg})$ & $52 \pm 5$ & $38 \pm 3^{*}$ & $39 \pm 4$ & $40 \pm 3$ & $39 \pm 3$ & $46 \pm 2$ & $35 \pm 2^{*}$ & $35 \pm 1^{*}$ & $38 \pm 3$ & $39 \pm 4$ \\
\hline PCWP (mm Hg) & $18 \pm 4$ & $11 \pm 1$ & $11 \pm 1$ & $10 \pm 1$ & $10 \pm 1$ & $15 \pm 3$ & $14 \pm 3$ & $12 \pm 2$ & $12 \pm 1$ & $13 \pm 1$ \\
\hline CVP $(\mathrm{mm} \mathrm{Hg})$ & $12 \pm 1$ & $10 \pm 1$ & $9 \pm 1$ & $9 \pm 1$ & $7 \pm 1^{*}$ & $12 \pm 1$ & $12 \pm 3$ & $10 \pm 2$ & $11 \pm 2$ & $12 \pm 1$ \\
\hline $\mathrm{CO}(\mathrm{L} / \mathrm{min})$ & $4.2 \pm 0.2$ & $4.5 \pm 0.2$ & $3.8 \pm 0.3$ & $3.8 \pm 0.5$ & $3.0 \pm 0.5$ & $4.2 \pm 0.2$ & $5.0 \pm 0.8$ & $4.1 \pm 0.2$ & $4.1 \pm 0.6$ & $4.2 \pm 0$. \\
\hline $\operatorname{SVR}\left(\mathrm{mm} \mathrm{Hg} \cdot \min \cdot \mathrm{L}^{-1}\right)$ & $29 \pm 3$ & $29 \pm 2$ & $37 \pm 2$ & $38 \pm 4$ & $46 \pm 8^{*}$ & $21 \pm 3$ & $24 \pm 2$ & $24 \pm 3$ & $25 \pm 2$ & $22 \pm 3$ \\
\hline PVR $\left(\mathrm{mm} \mathrm{Hg} \cdot \min \cdot \mathrm{L}^{-1}\right)$ & $8.4 \pm 0.8$ & $5.7 \pm 0.4^{*}$ & $7.7 \pm 0.9$ & $8.2 \pm 1.0$ & $10 \pm 1.3$ & $8.2 \pm 0.6$ & $4.9 \pm 0.4^{*}$ & $5.3 \pm 0.4$ & $5.7 \pm 0.5$ & $5.7 \pm 0$. \\
\hline HR (beats/min) & $135 \pm 26$ & $126 \pm 14$ & $125 \pm 18$ & $135 \pm 26$ & $130 \pm 28$ & $130 \pm 7$ & $124 \pm 21$ & $119 \pm 14$ & $130 \pm 21$ & $120 \pm 2$ \\
\hline
\end{tabular}

Hemodynamic parameters were measured before infusion (control) and after $30,60,90$, and 120 minutes of infusion. Data presented as mean \pm standard error of the mean. $H R$, Heart rate.

${ }^{*} p<0.05$, Friedman test for several related samples, versus values before infusion.

$\mathrm{U}-46619\left(250 \mathrm{ng} \cdot \mathrm{kg}^{-1} \cdot \mathrm{min}^{-1}\right)$ infused for 15 minutes were evaluated in control pigs $(n=5)$ and in animals receiving $10 \mathrm{mg} / \mathrm{kg}$ bosentan $(n=4)$. The dose of U-46619 was chosen on the basis of preliminary experiments $(n=$ 2, not shown) in which U-46619 was found to yield an increase in PVR in the range of that of hypoxia. ${ }^{15}$

ET infusion during hypoxia after bosentan administration. The effects of ET-1 infusion (25 and 100 $\left.\mathrm{ng} \cdot \mathrm{kg}^{-1} \cdot \mathrm{min}^{-1}\right)$ during hypoxia were studied in a control group $(n=4)$ and a group of pigs receiving $10 \mathrm{mg} / \mathrm{kg}$ bosentan intravenously $(n=4)$. After 5 minutes of hypoxia, the hemodynamic parameters were stable and baseline values during hypoxia were obtained. After 10 minutes of ET-1 infusion $\left(25 \mathrm{ng} \cdot \mathrm{kg}^{-1} \cdot \min ^{-1}\right.$ ), hemodynamic measurements were repeated. The ET-1 dose was then increased $\left(100 \mathrm{ng} \cdot \mathrm{kg}^{-1} \cdot \mathrm{min}^{-1}\right)$, and an additional hemodynamic recording was made after 10 minutes. The time intervals and doses of ET-1 infusions were based on results of the 2 -hour infusions and of previous work. $^{13}$

Statistical analysis. Results are presented as mean $( \pm$ standard error of the mean). The Friedman test for several related samples or the Mann Whitney $U$ test was used for statistical evaluation. A $p$ value lower than 0.05 was considered significant.

\section{Results}

Hemodynamic effects of 2 hours of hypoxia. Induction of hypoxia resulted in prompt increases in MPAP (from $25 \pm 2$ to $35 \pm 1 \mathrm{~mm} \mathrm{Hg}$ ) and PVR (from $3.0 \pm 0.1$ to $5.4 \pm 0.3 \mathrm{~mm} \mathrm{Hg} \cdot \min ^{-1} \cdot \mathrm{L}^{-1}$; $p<0.01$ ), a decrease in SVR, and an increase in heart rate. No clear-cut effects on PCWP (12 \pm 1 to $13 \pm 1 \mathrm{~mm} \mathrm{Hg}), \mathrm{CO}(4.2 \pm 0.3$ to $5.0 \pm 0.3 \mathrm{~L} / \mathrm{min})$, and CVP $(10 \pm 1$ to $11 \pm 1 \mathrm{~mm} \mathrm{Hg})$ were observed. The increases in MPAP and PVR remained unchanged during prolonged hypoxia (after 2 hours, MPAP $42 \pm 3 \mathrm{~mm} \mathrm{Hg}$, PVR $5.5 \pm 0.6 \mathrm{~mm}$ $\left.\mathrm{Hg} \cdot \min ^{-1} \cdot \mathrm{L}^{-1}\right)$. Hypoxia decreased the arterial oxygen tension to $3.4 \pm 0.3 \mathrm{kPa}$.
Effects of 2 hours of infusion of ET-1 and ET-3 during normoxia and hypoxia. Infusion of ET-1 (25 $\mathrm{ng} \cdot \mathrm{kg}^{-1} \cdot \min ^{-1}$ ) for 2 hours during normoxia evoked a gradual increase in PVR and SVR, whereas CO decreased (MPAP $25 \pm 1$ to $29 \pm 3 \mathrm{~mm}$ $\mathrm{Hg}$ after 2 hours infusion and PCWP $12 \pm 1$ to $11 \pm$ $1 \mathrm{~mm} \mathrm{Hg}$; Fig. 1). ET-3 (25 $\left.\mathrm{ng} \cdot \mathrm{kg}^{-1} \cdot \mathrm{min}^{-1}\right)$ evoked principally similar effects on SVR and CO, whereas no increase in PVR was observed (MPAP $26 \pm 1$ to $27 \pm 3 \mathrm{~mm} \mathrm{Hg}$ after 2 hours infusion and PCWP $11 \pm 1$ to $13 \pm 1 \mathrm{~mm} \mathrm{Hg}$; Fig. 1). During hypoxia, infusion of either ET-1 or ET-3 decreased PVR (Table I). This response diminished after prolonged infusion. No major effects on $\mathrm{CO}$ were observed after 2 hours of infusion of ET-1 or ET-3 in the hypoxic pigs, whereas SVR increased after 120 minutes of ET-1 infusion (Table I). Infusion of vehicle had no hemodynamic effects. ${ }^{13}$

Effects of S6c infusion during normoxia and hypoxia. S6c infusion $(10,25,50$, and 100 $\mathrm{ng} \cdot \mathrm{kg}^{-1} \cdot \min ^{-1}$ ) during normoxia evoked a dosedependent increase in PVR and SVR, whereas $\mathrm{CO}$ decreased (MPAP $26 \pm 1$ to $27 \pm 1 \mathrm{~mm} \mathrm{Hg}$ after $100 \mathrm{ng} \cdot \mathrm{kg}^{-1} \cdot \mathrm{min}^{-1}$ infusion and PCWP 12 \pm 1 to $16 \pm 1 \mathrm{~mm} \mathrm{Hg}$; Fig. 2). When PVR was increased by hypoxia, $S 6 \mathrm{c}$ infusion at the lower doses $\left(10\right.$ to $50 \mathrm{ng} \cdot \mathrm{kg}^{-1} \cdot \min ^{-1}$ ) caused an attenuation of this PVR increase (MPAP $41 \pm 2$ before infusion to $32 \pm 1 \mathrm{~mm} \mathrm{Hg}$ after 50 $\mathrm{ng} \cdot \mathrm{kg}^{-1} \cdot \mathrm{min}^{-1}$ infusion and PCWP $13 \pm 1$ to 15 $\pm 1 \mathrm{~mm} \mathrm{Hg}$ ), whereas effects on SVR and CO remained unchanged.

Effects of ET infusion after bosentan administration during normoxia. Intravenous administration of bosentan ( 3 or $10 \mathrm{mg} / \mathrm{kg}$ ) caused a decrease in MAP and SVR but did not influence MPAP, PVR, 

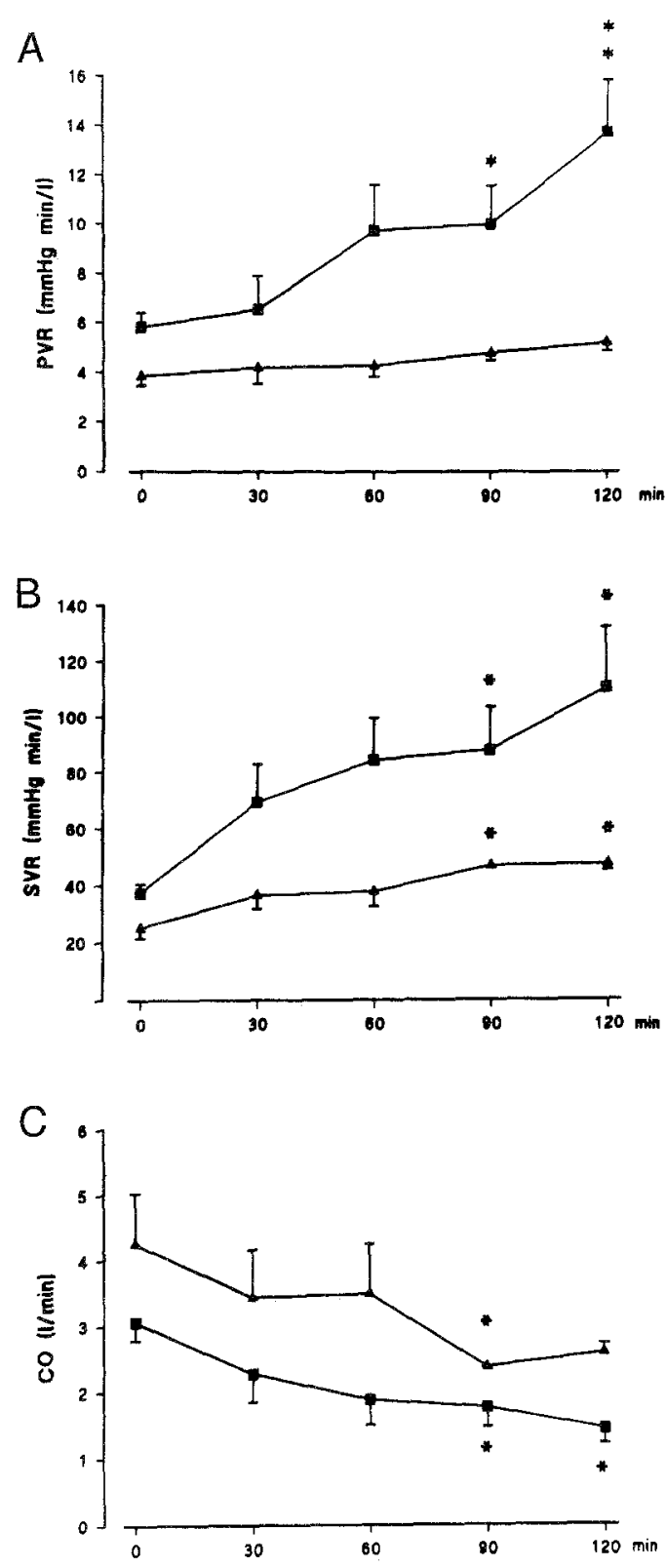

Fig. 1. A, PVR; B, SVR; and C, CO during normoxia and continuous infusion $\left(25 \mathrm{ng} \cdot \mathrm{kg}^{-1} \cdot \mathrm{min}^{-1}\right)$ of ET-1 ( and ET-3 (A). Error bars represent standard error of the mean. Asterisk indicates $p<0.05$ and double asterisk indicates $p<0.01$, Friedman test for several related samples, versus values before infusion.

$\mathrm{CO}$, or heart rate (Table II). Bosentan inhibited the increases in PVR and SVR evoked by ET-1 during normoxia (Fig. 3). The vehicle for bosentan, tested during normoxia and hypoxia $(n=2)$, was found to have no hemodynamic effects.
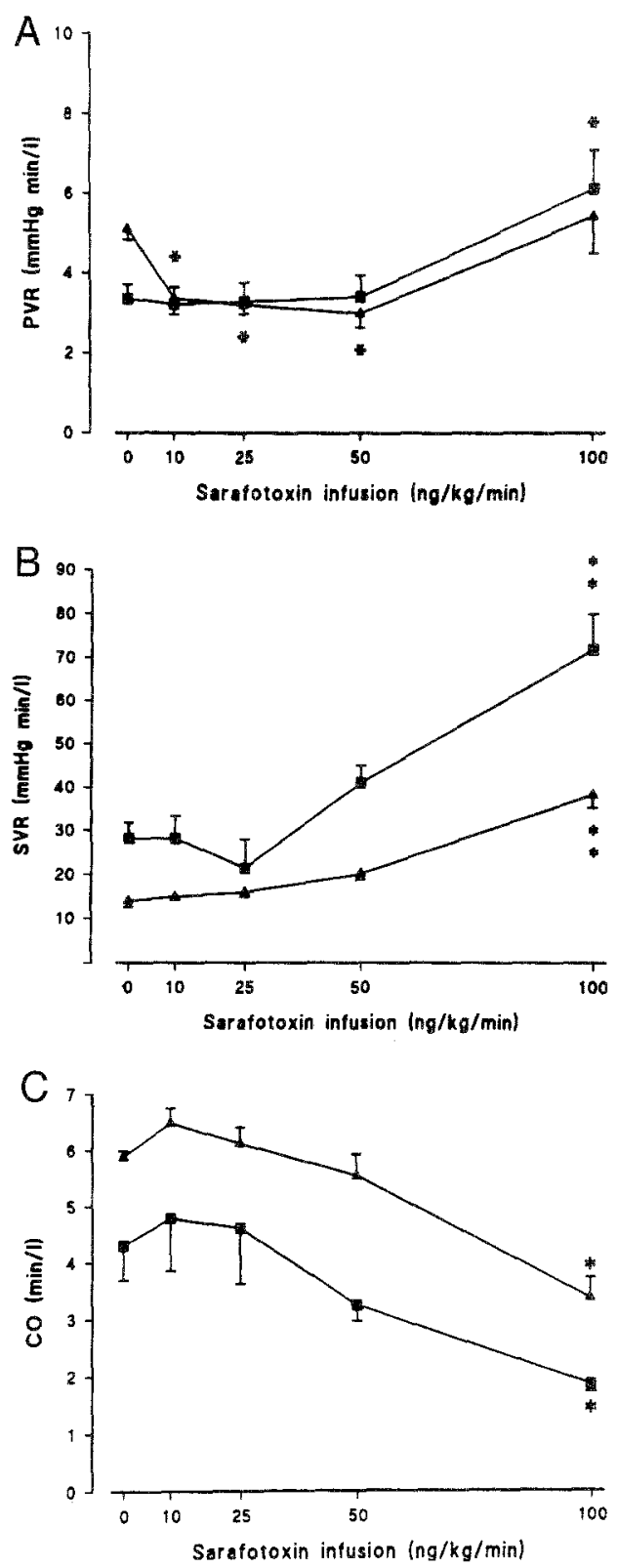

Fig. 2. Effects of S6c infusion (10, 25, 50, and 10025 $\mathrm{ng} \cdot \mathrm{kg}^{-1} \cdot \mathrm{min}^{-1}$ infused for 10 minutes each) on A, PVR; $\mathbf{B}$, SVR; and C, CO in normoxic ( $\mathbf{D}$ ) and hypoxic ( animals. Error bars represent standard error of the mean. Asterisk indicates $p<0.05$ and double asterisk indicates $p<0.01$, Friedman test for several related samples, versus values before infusion.

Effects of bosentan on pulmonary hypertension induced by hypoxia or U-46619. When hypoxia was established after bosentan administration, there was a reduction of the vasopressor response in the pulmonary circulation. At the higher dosage of 
Table II. Influence of intravenous bosentan administration at 3 and $10 \mathrm{mg} / \mathrm{kg}$ on hemodynamic parameters during normoxia and hypoxia

\begin{tabular}{|c|c|c|c|c|c|c|}
\hline & \multicolumn{3}{|c|}{ Normoxia } & \multicolumn{3}{|c|}{ Hypoxia } \\
\hline & \multirow[b]{2}{*}{ Control } & \multicolumn{2}{|c|}{ Bosentan } & \multirow[b]{2}{*}{ Control } & \multicolumn{2}{|c|}{ Bosentan } \\
\hline & & $3 \mathrm{mg} / \mathrm{kg}$ & $10 \mathrm{mg} / \mathrm{kg}$ & & $3 \mathrm{mg} / \mathrm{kg}$ & $10 \mathrm{mg} / \mathrm{kg}$ \\
\hline MAP (mm Hg) & $128 \pm 5$ & $98 \pm 7^{*}$ & $95 \pm 6^{*}$ & $118 \pm 5$ & $88 \pm 4 \uparrow$ & $94 \pm 5 \uparrow$ \\
\hline MPAP (mm Hg) & $20 \pm 2$ & $22 \pm 1$ & $17 \pm 1$ & $43 \pm 2$ & $42 \pm 2$ & $26 \pm 2+$ \\
\hline PCWP (mm Hg) & $12 \pm 2$ & $11 \pm 1$ & $9 \pm 1$ & $13 \pm 1$ & $12 \pm 1$ & $9 \pm 1$ \\
\hline CVP (mm Hg) & $8 \pm 1$ & $7 \pm 2$ & $6 \pm 1$ & $10 \pm 1$ & $10 \pm 1$ & $8 \pm 1$ \\
\hline $\mathrm{CO}(\mathrm{L} / \mathrm{min})$ & $3.6 \pm 0.3$ & $3.5 \pm 0.4$ & $3.6 \pm 0.4$ & $4.2 \pm 0.2$ & $4.9 \pm 0.7$ & $4.4 \pm 0.5$ \\
\hline $\operatorname{SVR}\left(\mathrm{mm} \mathrm{Hg} \cdot \min \cdot \mathrm{L}^{-1}\right)$ & $35 \pm 2$ & $27 \pm 4$ & $27 \pm 3 \dagger$ & $25 \pm 2$ & $17 \pm 2 \dagger$ & $21 \pm 2 \dagger$ \\
\hline PVR $\left(\mathrm{mm} \mathrm{Hg} \cdot \min \cdot \mathrm{L}^{-1}\right)$ & $2.4 \pm 0.3$ & $3.1 \pm 0.1$ & $2.2 \pm 0.3$ & $7.6 \pm 0.5$ & $6.4 \pm 0.6$ & $4.3 \pm 0.7 \dagger$ \\
\hline HR (beats/min) & $91 \pm 4$ & $82 \pm 3$ & $87 \pm 9$ & $123 \pm 8$ & $120 \pm 12$ & $108 \pm 12$ \\
\hline
\end{tabular}

Data presented as mean \pm standard error of the mean. $H R$, Heart rate.

* $p<0.01$, Friedman test for several related samples, versus values before infusion.

$\dagger p<0.05$, Friedman test for several related samples, versus values before infusion.

$\dot{f} p<0.001$, Friedman test for several related samples, versus values before infusion.

bosentan $(10 \mathrm{mg} / \mathrm{kg})$, MPAP and PVR during hypoxia were significantly lower than in control animals (Table II). U-46619 caused a rapid increase in MPAP $(26 \pm 1$ to $54 \pm 8 \mathrm{~mm} \mathrm{Hg})$ and PVR $(3.9 \pm$ 0.4 to $\left.12.2 \pm 2.8 \mathrm{~mm} \mathrm{Hg} \cdot \min \cdot \mathrm{L}^{-1}\right)$. Bosentan $(10$ $\mathrm{mg} / \mathrm{kg}$ ) did not influence the response to U-46619 (MPAP $52 \pm 2 \mathrm{~mm} \mathrm{Hg}$ and PVR $9.5 \pm 1.2 \mathrm{~mm}$ $\left.\mathrm{Hg} \cdot \min \cdot \mathrm{L}^{-1}\right)$.

ET infusion during hypoxia after bosentan administration. ET-1 infusion $\left(25\right.$ or $100 \mathrm{ng} \cdot \mathrm{kg}^{-1} \cdot \mathrm{min}^{-1}$ for 10 minutes) caused a reduction of PVR during hypoxia (Fig. 4). The increase in PVR during hypoxia was reduced after bosentan administration, and subsequent infusion of ET-1 did not evoke any further reduction of the PVR.

Plasma ET-1 levels and blood gas values. Neither ET nor bosentan influenced arterial or venous blood gas values ( $\mathrm{pH}$, oxygen tension, and carbon dioxide tension) during normoxia or hypoxia (not shown). Bosentan administration increased both the arterial and venous circulating ET- 1 levels $(8.4 \pm 1.2$ to $24.1 \pm 4.6 \mathrm{fmol} / \mathrm{ml}$ in the aorta and $8.1 \pm 1.8$ to 21.1 $\pm 2.5 \mathrm{fmol} / \mathrm{ml}$ in the pulmonary artery). The levels of circulating ET-1 did not change significantly during hypoxia (as long as 2 hours, not shown).

\section{Discussion}

In this study, we evaluated the involvement of ET in hypoxic pulmonary hypertension by means of a large-animal in vivo model. Previous work has shown that repeated 15-minute periods of hypoxia in pigs produce stable, reproducible hemodynamic changes; namely, consistent increases in MPAP and PVR. ${ }^{13}$ The main effect of ET-1, ET-3, and S6c on the pulmonary and systemic vascular beds is vasoconstriction during normoxic conditions. The concomitant decrease in $\mathrm{CO}$ could be related to the increase in SVR, although coronary vasoconstriction $^{19}$ or a direct negative inotropic effect ${ }^{20}$ cannot be excluded. In contrast, when the PVR was increased during hypoxia, exogenous ET-1, ET-3, and S6c all reduced PVR. This effect (in the case of ET-1 and ET-3) lasted at least 30 minutes, suggesting that tachyphylaxis does not occur during this time..$^{13}$ The observation that changes in PVR in all major aspects were accompanied by changes in MPAP supports the contention that this reflects active alterations in the vasomotor tone of the pulmonary vascular bed. In accord, a previous study demonstrated pulmonary vasodilation without any evidence of short-term tolerance during ET-1 administration after hypoxic pulmonary hypertension when $\mathrm{CO}$ was kept constant. ${ }^{21}$

This study demonstrated that ET antagonism with bosentan reduces both the dose-dependent pressor response to ET-1-infusion in the pulmonary and systemic circulation during normoxia and the development of pulmonary hypertension during hypoxia. In addition, the vasodilator capacity of ET during hypoxia-evoked increases in PVR is attenuated by bosentan. The selectivity of bosentan for ET receptors was supported by the finding that the pulmonary vasopressor response to U-46619 remained unchanged after bosentan administration.

Previous studies of the hemodynamic effects of ET-1 on the pulmonary circulation demonstrated inconsistent and partially conflicting results. Low doses of ET-1 produced pulmonary vasodilation in 

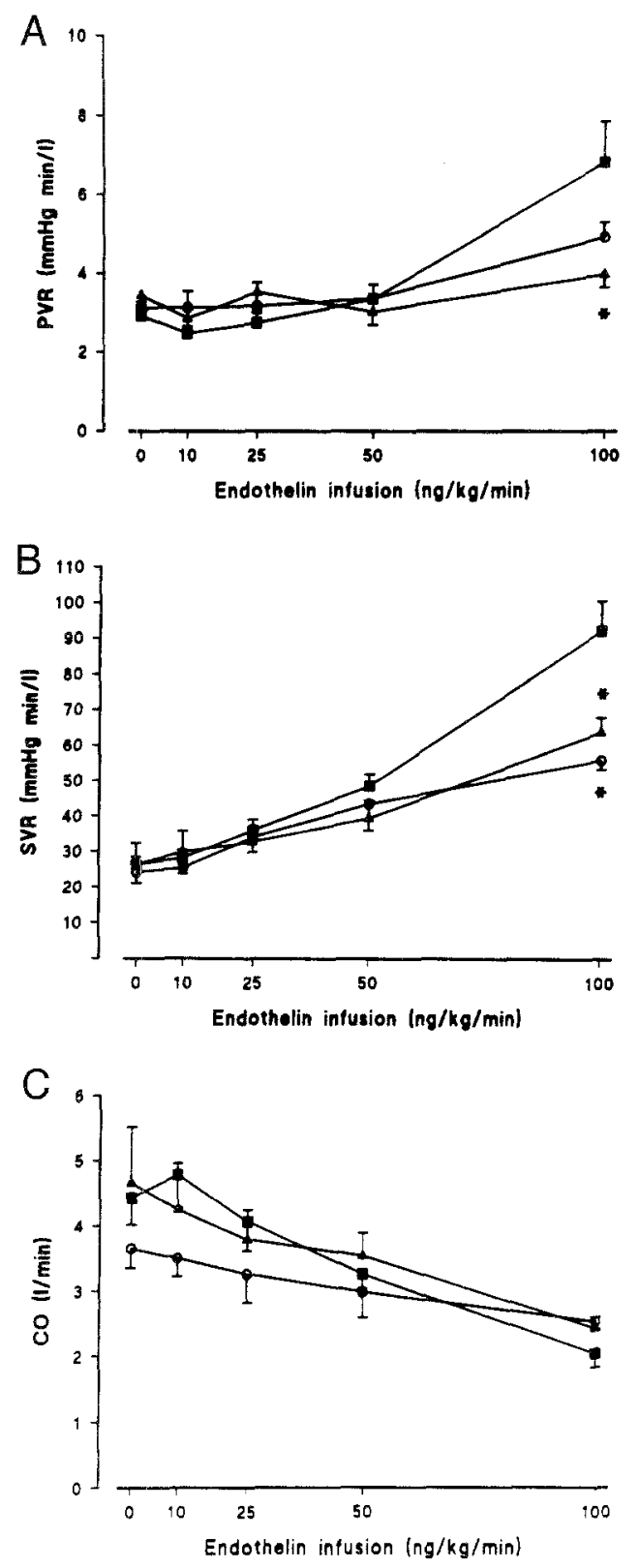

Fig. 3. A, PVR; B, SVR; and C, CO during normoxia and increasing doses of ET-1 $(10,25,50$, and 100 $\mathrm{ng} \cdot \mathrm{kg}^{-1} \cdot \mathrm{min}^{-1}$ infused for 10 minutes each) in control animals ( $\mathbf{a})$ and after intravenous administration of 3 $\mathrm{mg} / \mathrm{kg}(\bigcirc)$ or $10 \mathrm{mg} / \mathrm{kg}(\mathbf{\Lambda})$ bosentan. Error bars represent standard error of the mean. Asterisk indicates $p<0.05$, Mann-Whitney $U$ test.

the newborn piglet, whereas higher doses elicited vasoconstriction. ${ }^{5}$ In intact newborn lambs, ET-1 produced pulmonary vasodilation during hypoxic pulmonary hypertension, ${ }^{22}$ whereas in fetal sheep ET-1 decreased the pulmonary vascular resistance
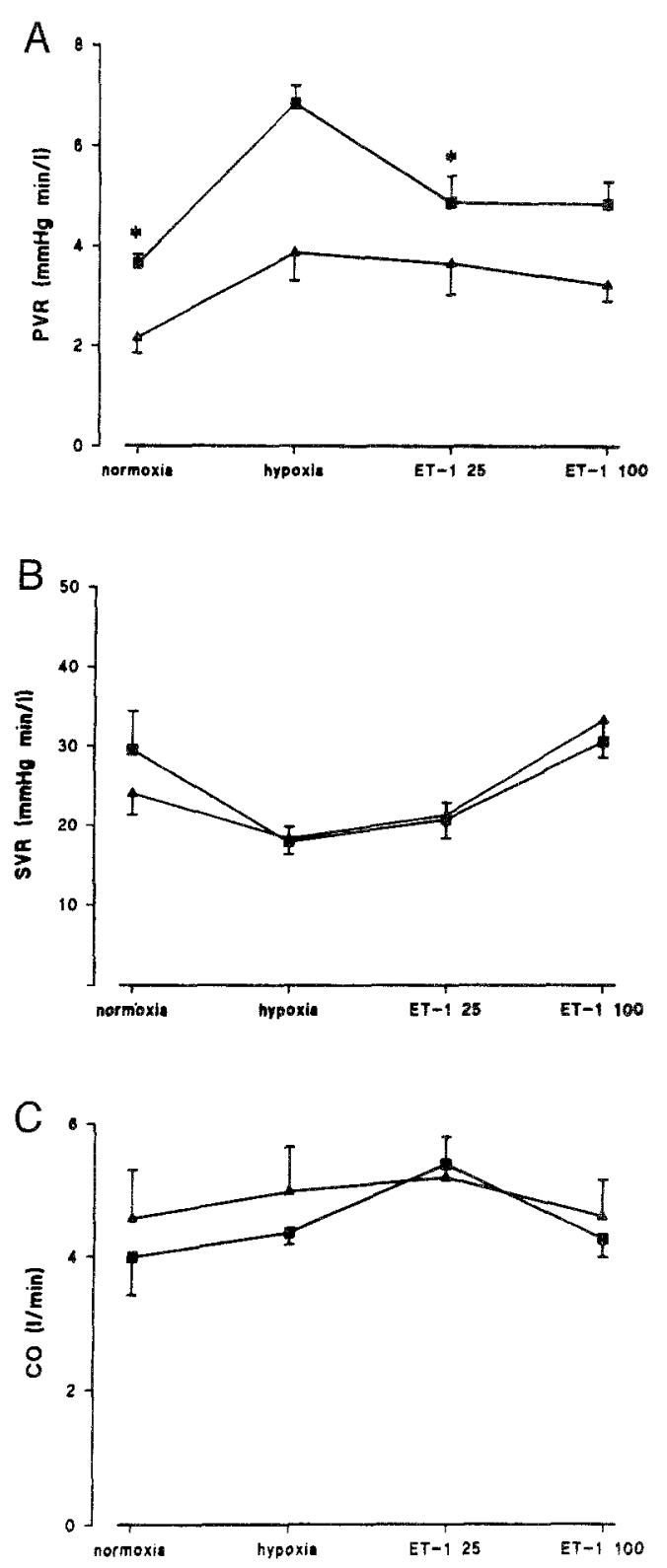

Fig. 4. Effects on A, PVR; B, SVR; and C, CO of 5 minutes of hypoxia followed by infusion of ET-1 (25 and $100 \mathrm{ng} \cdot \mathrm{kg}^{-1} \cdot \mathrm{min}^{-1}$ infused for 10 minutes each) in the absence ( $)$ or presence $(\mathbf{A})$ of bosentan $(10 \mathrm{mg} / \mathrm{kg})$. Error bars represent standard error of the mean. Asterisk indicates $p<0.05$ versus hypoxia, Friedman test for several related samples.

when infused into the pulmonary artery but produced vasoconstriction when infused into the superior vena cava. ${ }^{23}$ Furthermore, in older animals (calves and adult pigs), ET-1 dilated the pulmonary circulation during hypoxic pulmonary vasoconstriction. $^{21,13}$ The heterogeneity of the ET-receptor 
population could explain some of the differences in effects of ET-1 observed in the pulmonary circulation. It has therefore been suggested that the pulmonary vasodilator effect of ET-1 in low doses during acute hypoxia is mediated by $\mathrm{ET}_{\mathrm{B}}$ receptors located on the endothelium. ${ }^{3,13}$ Activation of ET receptors could subsequently produce vasoconstriction or vasodilation, depending on dose of ET administered, mode of administration, species studied, and vascular bed studied. This study demonstrates that the predominant response to activation of ET receptors in the pulmonary circulation in pigs during acute hypoxia is vasoconstriction, because bosentan resulted in a reduction of the vasoconstrictor response. This suggests that vasocontractile ET receptors on vascular smooth muscle are activated by ET released during acute hypoxia, which is in accord with the primarily abluminal release of endogenous ET. ${ }^{24}$ Conversely, the vasodilator response to ET-1 administered in low doses during acute hypoxia could be attributed to activation of $\mathrm{ET}_{\mathrm{B}}$ receptors on the vascular endothelium. ${ }^{13}$ Our results with S6c also imply that the vasodilator effect during hypoxia is indeed mediated by $\mathrm{ET}_{\mathrm{B}}$-receptor activation, although S6c has also been shown to cause vasoconstriction of isolated blood vessels. ${ }^{25}$ Autoradiographic studies, however, have shown a predominance of $\mathrm{ET}_{\mathrm{A}}$ receptors and a lack of $\mathrm{ET}_{\mathrm{B}^{-}}$ mediated vasoconstriction in human pulmonary arteries. The attenuation of SVR during normoxia by bosentan, independent of other influences, suggests the existence of an endogenous vasocontractile "endothelin tone" in the systemic circulation. It is generally considered that the pulmonary circulation is dilated during normoxia, a contention supported in this study by the observation that PVR at normoxia remained unchanged after bosentan administration.

ET antagonism with bosentan results in a clearcut increase in the levels of circulating ET-1, which is in accord with previous findings. ${ }^{26}$ The absence of increases in the levels of circulating ET during hypoxia may be explained by abluminal release of ET to the vascular smooth muscle cells, ${ }^{24}$ although peripheral plasma concentration may not accurately reflect the concentration of ET at local release sites. Furthermore, prolonged hypoxia may be needed to increase circulating levels of ET. ${ }^{27,28}$ In human beings, the circulating plasma levels of ET-1 are low under normal conditions but elevated in a variety of pathologic conditions, including pulmonary hypertension. ${ }^{29,30}$ The beneficial effects of combined $\mathrm{ET}_{\mathrm{A}^{-}}$and $\mathrm{ET}_{\mathrm{B}^{-}}$-receptor antagonism in clinical con- ditions associated with pulmonary hypertension therefore remain to be established. Bosentan has interesting properties in this context; bosentan is the first orally active, nonselective, nonpeptide ET-receptor antagonist.

\section{REFERENCES}

1. Yanagisawa M, Kiruhara H, Kimura S, Tomobe $\mathrm{Y}$, Kobayashi M, Mitsui Y, et al. A novel potent vasoconstrictor peptide produced by vascular endothelial cells. Nature 1988; 332:411-5.

2. Inoue $A$, Yanagisawa M, Kimura $S$, Katsuya $Y$, Miyauchi $T$, Goto $\mathrm{K}$, et al. The human endothelin family: three structurally and pharmacologically distinct isopeptides predicted by three separate genes. Proc Natl Acad Sci U S A 1989;86:2863-7.

3. Stewart DJ, Langleben D. Endothelin and pulmonary hypertension. In: Lüscher TF ed. The endothelium in cardiovascular disease. New York: Springer-Verlag 1995:184-95.

4. Horgan MJ, Pinheiro JM, Malik AB. Mechanism of endothelin-1 induced pulmonary vasoconstriction. Circ Res 1991; 69:157-64.

5. Bradley LM, Czaja JM, Goldstein RE. Circulatory effects of endothelin in newborn piglets. Am J Physiol 1990;259(5 Pt 2):H1613-7.

6. Lippton HL, Gordon CA, McMurtry IF, Hyman AL. Pulmonary vasodilation to endothelin isopeptides is mediated by potassium channel activation. J Appl Physiol 1991;70:947-52.

7. Hasunuma K, Rodman DM, O'Brien RF, McMurtry IF Endothelin 1 causes pulmonary vasodilatation in rats. Am $\mathrm{J}$ Physiol 1990;259(1 Pt 2):H48-54.

8. Cernacec $\mathrm{P}$, Stewart DJ. Immunoreactive endothelin in human plasma: marked elevation in patients with cardiogenic shock. Biochem Biophys Res Commun 1989;161:562-7.

9. Yoshibayashi M, Nishioka K, Nakao K, Saito Y, Matsumura M, Ueda $\mathrm{T}$, et al. Plasma endothelin concentrations in patients with pulmonary hypertension associated with congenital heart defects: evidence for increased production of endothelin in pulmonary circulation. Circulation 1991;84:2280-5.

10. Vincent JA, Ross RD, Kassab J, Hsu JM, Pinsky WW. Relation of elevated plasma endothelin in congenital heart disease to increased pulmonary blood fiow. Am J Cardiol 1993;71:204-7.

11. Allen SW, Chatfield BA, Koppenhafer SA, Schaffer MS, Wolfe RR, Abman SH. Circulating immunoreactive endothelin-1 in children with pulmonary hypertension. Am Rev Respir Dis 1993;148:519-22.

12. Komai H, Adiata IT, Elliott MJ, de Leval MR, Haworth SG. Increased plasma endothelin-1 after cardiopulmonary bypass in patients with pulmonary hypertension and congenital heart disease. $J$ Thorac Cardiovasc Surg 1993;106:473-8.

13. Liska J, Holm P, Öwall A, Franco-Cereceda A. Endothelin reduces hypoxic pulmonary hypertension in pigs in vivo. Acta Physiol Scand 1995;154:489-98.

14. Clozel M, Breu V, Gray GA, Kalina B, Löffer BM, Burri K, et al. Pharmacological characterization of bosentan, a new potent orally active nonpeptide endothelin receptor antagonist. J Pharmacol Exp Ther 1994;270:228-35.

15. Kiowski W, Sütsch G, Hunziker P, Müller P, Kim J, Oechslin $\mathrm{E}$, et al. Evidence for endothelin-1-mediated vasoconstriction in severe chronic heart failure. Lancet 1995;345:732-6. 
16. Lippton HI, Hauth TA, Cohen GA, Hymn AL. Functional evidence for different endothelin receptors in the lung. J Appl Physiol 1993;75:38-48.

17. Williams DL, Jones KL, Pettibone DJ, Lis EV, Clineschmidt BV. Sarafotoxin 6c: an agonist which distinguishes between endothelin receptor subtypes. Biochem Biophys Res Commun 1991;175:556-61.

18. Franco-Cereceda A, Rydh M, Lou Y, Dalsgård CJ, Lundberg JM. Endothelin as putative sensory neuropeptide in the guinea-pig: different properties in comparison with calcitonin gene-related peptide. Reg Pept 1991;32:253-65.

19. Franco-Cereceda A. ET- and NPY-induced vasoconstriction of human coronary arteries in vitro. Br J Pharmacol 1989;97: 968-72.

20. Franco-Cereceda A, Matran R, Lou Y-P, Lundberg J. Occurrence and effects of endothelin in the guinea pig cardiopulmonary tissue. Acta Physiol Scand 1990;137:539-47.

21. Deleuze PH, Adnot S, Shiiya N, Roudot Thoravel F, Eddahibi S, Braquet $\mathrm{P}$, et al. Endothelin dilates bovine pulmonary circulation and reverses hypoxic pulmonary vasoconstriction. J Cardiovasc Pharmacol 1992;19:354-60.

22. Wong J, Vanderford PA, Fineman JR, Chang R, Soifer SJ. Endothelin-1 produces pulmonary vasodilation in the intact newborn lamb. Am J Physiol 1993;265(4 Pt 2):H131824.

23. Chateld BA, McMurtry IF, Hall SL, Abman S. Hemodynamic effects of endothelin-1 on ovine fetal pulmonary circulation. Am J Physiol 1991;261 (Regulatory Integrative Comp Physiol 30):R182-7.

24. Seo B, Oemar BS, Siebenmann R, von Segesser L, Lüscher $\mathrm{TF}$. Both $\mathrm{ET}_{\mathrm{A}}$ and $\mathrm{ET}_{\mathrm{B}}$ receptors mediate contraction to endothelin-1 in human blood vessels. Circulation 1994;89: 1203-8.

25. Fukuroda T, Kobayashi M, Ozaki S, et al. Endothelin receptor subtypes in human versus rabbit pulmonary arteries. J Appl Physiol 1994;76:1976-82.

26. Wagner OF, Christ G, Wojta J, Vierhapper H, Parzer S, Nowotny PJ, et al. Polar secretion of endothelin-1 by cultured endothelial cells. J Biol Chem 1992;267:16066-8.

27. Goerre S, Wenk M, Bärtsch P, Lüscher TF, Niroomand F, Hohenhaus $E$, et al. Endothelin-1 in pulmonary hypertension associated with high-altitude exposure. Circulation 1995;90; 359-64.

28. Kourembanas S, Marsden PA, McQuillan LP, Faller DV. Hypoxia induces endothelin gene expression and secretion in cultured human endothelium. J Clin Invest 1991;88: 1054-7.

29. Stewart DJ, Levy RD, Cernacek P, Langleben D. Increased plasma levels of endothelin-1 in pulmonary hypertension: marker or mediator of disease? Ann Intern Med 1991;1141: 464-9.

30. Chang $\mathrm{H}$, Wu GJ, Wang SM, Hung CR. Plasma endothelin levels and surgically correctable pulmonary hypertension. Ann Thorac Surg 1993;55:450-8. 